\title{
Utilization of Coconut Fiber as a Poor Households Empowerment Base (A Case in Bongomeme District of Gorontalo Regency, Indonesia)
}

\author{
Muhammad Obie ${ }^{1}$, Asna Usman Dilo ${ }^{2}$, Syilfi $^{3}$ \& Ita Meiyarni ${ }^{3}$ \\ ${ }^{1}$ Department of Sociology, State Islamic University of Sultan Amai Gorontalo, Indonesia \\ ${ }^{2}$ Department of Language Center, State Islamic University of Sultan Amai Gorontalo, Indonesia \\ ${ }^{3}$ Faculty of Education and Teacher Training, State Islamic University of Sultan Amai Gorontalo, Indonesia \\ Correspondence: Muhammad Obie, Department of Sociology, State Islamic University of Sultan Amai Gorontalo, \\ Indonesia. Tel: 62-8135-479-0642. E-mail: obiclimber@gmail.com
}

Received: April 22, 2018

Accepted: May 5, 2019

Online Published: May 30, 2019

doi:10.5539/mas.v13n6p68

URL: https://doi.org/10.5539/mas.v13n6p68

\begin{abstract}
Poor households have not utilized coconut fiber that is very potential to improve their welfare. This study analyzed the root causes of poor households not yet utilizing the potential of coconut fiber craft as a source of livelihood. The potential of crafts that can be developed from coconut fiber and the strategy of building institutional, commercial business groups of poor households are based on the manufacture of coconut fiber crafts to be competitive and sustainable. The researchers collected data through observation, in-depth interviews, focused group discussion, and literature review. The results show that lack of knowledge is at the root of the leading cause of poor households not utilizing coconut fiber as their livelihood. The other causes are lack of skills, low education, weak access to information, lack of collective awareness, and a false understanding that coconut fiber handicraft products are not sold in the market. Even though the facts show that if processed into handicraft products, coconut fiber can be used by poor households to improve their welfare so that they can be economically empowered. Various strategies can be carried out to build the institutional economic business groups of poor households based on the manufacture of coconut fiber crafts, namely critical awareness, strengthening the capacity of poor households, both through skills training, on the job training, and in-service training. Besides, comparative studies of entrepreneurship can also be carried out, opening up access to information, opening access to micro-business financing, and building networks of poor households to the outside world.
\end{abstract}

Keywords: coconut fiber, poor households, community empowerment, handicraft products

\section{Introduction}

Coconut plant is one of the plantation commodities that is very potential and grows in almost all parts of Indonesia. These plants can be used almost entirely for economic improvement, starting from the roots in the soil to the leaves and fruit on the top of the tree. Apart from its contents having economic value, coconut fiber can also be used to improve welfare. Indahyani Study (2011) on the topic "Utilization of Coconut Fiber Waste in Interior and Furniture Planning that Impacts the Empowerment of the Poor," concluded that coconut fiber could be processed into a variety of finished and semi-finished products that have high selling value. These products include coir, mat, coir fiber (coco fiber), coir powder (cocopeat), solid coir powder (coco peat brick), coco pot, coco sheet, coco fibreboard (CFB) and coco coir.

Sulistiani's research (2014) with the topic, "Utilization of Coconut Fibers in Improving Organic Fertilizer Quality from Tofu Dregs", concluded that the combination of star-bio and EM4 bioindicators and the addition of coconut fibers can improve the decomposition process of organic compounds but the levels are still higher than the fertilizer quality limit recommended in the SNI 19-7030-2004 standard. Paskawati et al., (2010) research with the topic, "Utilization of Coconut Fiber as an Alternative Composite Paper Raw Material", concluded that coco fiber has a high cellulose content so that the fiber can be used as pulping material, which can then be utilized in manufacture of composite paper material consisting of a mixture of coco fiber pulp and VHS forming pulp.

The research by Dharma et al. (2018) on the topic, "The Study of the Use of Coconut Fiber Waste into Local 
Microorganisms Solution," concluded that the research results of coconut husk MOL solution contained a bioactivator and fertilizer with high K content. Research by Titani et al., (2018) with the topic, "Utilization of Coconut Fibre as Strengthening Material for Fiberglass Replacement in Polyester Resin Composites for Aircraft Construction Materials Applications," concluded that the more fractions of coconut fiber were added, the more energy absorbed in impact testing will be higher. It is because the bond between the matrix and coco fiber can make the composite material resistant to impact if subjected to a load. The study of Trikarlina et al., (2018), with the topic, "Utilization of Coconut Coir (Cocos nucifera L.) and the Effect of Addition of Sikacim Concrete Additive to Brick Making", concluded that the composition of coconut coir ash and cyclic concrete additive were used, then the cement paste will dry out faster in terms of the initial and final binding times.

Many of the economic benefits of coconut fiber as the results of the study above, unfortunately, not all regions in Indonesia can use it. In Bongomeme District, Gorontalo Regency, for example, coconut fiber is available in very abundant quantities. This coconut coir comes from copra processing waste. However, the community has not used it well. Poor households that are supposed to be able to use coconut fiber as an economical source have not yet known well the benefits of coconut fiber which can be processed into high economic value crafts. So far, local people consider coconut fiber only as garbage. Ironically, the poverty that surrounds poor households in Bongomeme Subdistrict, Gorontalo Regency, is very alarming. The regional government program, both the Gorontalo Provincial Government and the Gorontalo District Government, did not touch the root of the problem of poor households. It makes poor households wallow in poverty. Approximately 321 heads of households consisting of 1,122 people, households in Bongomeme Subdistrict live below the poverty line. These poor households are spread in four villages, which are the focus of research. Poor households in the four villages that became the target of the study lived in very uncertain economic conditions due to the absence of sources of livelihood. Minimal skill factors and the absence of agricultural land added to the gloomy days they had to go through. It results in marginalized households in social life. Meanwhile, coconut fiber which should be processed as a source of livelihood because it has enormous economic potential is wasted.

This study answers the question of why poor households have not utilized the potential of coconut fiber craft to become a source of livelihood. What are the potentials of craft that can be developed from coconut fiber and how the strategy of developing institutional, commercial business groups of poor households is based on the manufacture of coconut fiber crafts to be competitive and sustainable? By answering the problems faced in utilizing coconut fiber, poor households are expected to achieve economic empowerment. Theoretically, empowerment is one of the insights of alternative development that has developed such as eco-development, people-centered development, sustainable development that refers to a process from a particular condition to an expected condition. Empowerment is defined as empowering, from powerless to powerful. Economists mainly initiated the concept of empowerment, especially to overcome the problem of poverty. Chambers (1995) stated that community empowerment is an economic development concept that summarises social values. This concept reflects the new paradigm of development, namely the nature of people-centered, participatory, empowering, and sustainable. Pranarka and Moeljarto (1996) stated that empowerment is an effort to stimulate, encourage, or motivate individuals to have the ability or empowerment to determine life choices.

The community in the empowerment perspective is authorized to manage development funds both from the government and from other parties. Also, they must participate in the process of selecting, planning, and implementing development (Soetrisno, 2000). Mujiyadi and Gunawan (2000) explained that in the process of empowerment, in essence, two essential things are met, namely the needs and potential. Oakley and Masden (1984) in Pranaka and Moeljarto (1996) stated that the empowerment process contains two tendencies. Firstly is a process that emphasizes the transfer of some power, strength, or ability to the community to be more empowered. The secondary, empowerment that emphasizes the process of stimulating, encouraging, or motivating the community to have the ability or empowerment to determine what is their life choice through a dialogue process.

\section{Research Methods}

The target of this study was the poor households. The location of the research focus was Bongomeme District, Gorontalo Regency, Gorontalo Province. The researchers selected informants as primary data sources through purposive sampling and snowball techniques. The technique of determining informants was purposive, which means that the selection of informants based on rational considerations of researchers who were considered to have the competence to provide information or data expected by the author. Herdiansyah (2011) stated that purposive sampling is used to select the subject and location of the study in order to study and understand the problems and objectives of the study.

Data collection was done through several techniques, namely observation, in-depth interviews, Focused Group 
Discussion (FGD), and literature review. In this research, Observers were making observations on the subject of the study openly (see Stainback, in Sugiyono, 2009). In-depth interviews are conversations with specific intentions (Moleong, 2007). According to Banister et al. in Poewarndari (2007), interviews are conversations and question and answer that are directed at achieving specific goals. Interviews in a qualitative approach are to obtain knowledge about subjective meanings that are understood by individuals concerning the topic under study in order to explore the issue, something that no other approach can do. Nasir (2003) defined interview as the process of obtaining information for research purposes using question and answer, face to face between interviewers and respondents using a tool called an interview guide.

The purpose of conducting interviews is among others to construct about people, events, organizations, feelings, motivations, demands, concerns, and others (Lincoln and Guba, 1985; in Moleong, 2007). In this study, researchers applied semi-structured interviews. This type of interview is included in the in-depth interview category, where the implementation is freer when compared to structured interviews. The purpose of semistructured interviews is to find the problems more openly, where the interviewees are asked for their opinions and ideas. In conducting interviews, researchers need to listen carefully and record what the informants said (see Esterberg, 2002; in Sugiyono, 2009). As for the literature review is a method of collecting data from existing literature. In this study, researchers reviewed the literature to support field data. Thus, the data obtained from the literature review is secondary data.

Data collection was also done through FGD, which was to explore the topic of the problem more deeply and to get more precise information because it allows the FGD participants to check the information submitted to each other. According to Kriyantono (2006), the FGD method is as a technique of collecting data to understand the attitudes and behavior of audiences and unstructured discussions with topics prepared. The things that must be considered in the FGD are: (1) There are no right or wrong answers; each FGD participant must feel free to answer according to the discussed issues. (2) all interactions and conversations must be recorded properly. (3) discussion must proceed with an informal atmosphere so that participants can comment (enthusiastically) even if they are not asked directly so that there is a dynamic exchange of opinions.

Nasir (2003) revealed that data analysis is grouping, making a sequence, manipulating, and abbreviating data so that it is easy to read. Another definition of data analysis is put forward by Poerwandari (2007), where actual data processing and analysis starts with organizing data. Many and varied qualitative data is the obligation of researchers to organize their data neatly, systematically, and as completely as possible. Highlen and Finley in Poerwandari (2007) stated that data organization allows researchers to obtain good quality data, document the analysis carried out, and store data and analysis related to the completion of the study.

\section{Results and Discussion}

\subsection{The root of the Problem Causes of Poor Households Not Utilizing Coconut Fiber as a Livelihood Source}

There are many causes for poor households not to use coconut fiber as a source of livelihood. The first is the lack of knowledge regarding the use of coconut fiber. A very ironic fact was found in the research location that coconut husk had not been used properly. The lack of knowledge of poor households on the processing of coconut fiber is the main cause. The coconut husk that is available is quite a lot in the research location, even by residents it is considered as garbage. According to the habits of residents, coconut husk, which is a waste from the processing of copra, is destroyed by burning or being transported to a landfill. This habit is very ironic because there are so many benefits that can be obtained from processing coconut fiber.

Second, poor households lack skills. The absence of skills is also one of the root causes of poor households in utilizing coconut fiber crafts. Poor households in the study locations have never received training to process coconut fiber into economically valuable crafts. As a result, these marginal groups have no skills at all to produce coconut fiber based crafts.

Another reason is that creativity is low because of limited education. Low education seems to be a negative image for poor households in the countryside. This limited education causes low creativity for poor households. Of the many households that were the object of research, most of them only had primary education, many of them did not even complete this level of primary education.

The low access to quality information is also the reason why poor households have not used coconut fiber as a basis for livelihoods. The primary access to information for poor rural households is television broadcasts. There is no access to information through books, newspapers, or scientific journals. According to Yusup et al. (2017), rural poor people access information through informal interpersonal communication. They prefer to ask neighbors or close relatives. In such conditions, quality and essential information regarding their livelihood are doubtful for 
them to obtain. As a result, they continued to wallow in poverty and underdevelopment. The potential of resources that should be utilized to lift their welfare is impossible. Likewise, the information regarding the processing of coconut fiber, which has been widely studied into economically valuable handicraft products, is not obtained.

Another reason is the lack of collective awareness of the utilization of the local potential of coconut fiber. Coconut coir, which has high economic potential, does not provide benefits to poor households at the research location. Poor households appear collectively to have no awareness to process coconut fiber into handicraft products. Poor households collectively pursue corn farming even though the results are not encouraging because of the limited agricultural land they have. The final reason is that there is a false understanding of poor households that coconut fiber handicrafts are not sold in the market. Poor households assume that coconut fiber handicraft products cannot be marketed. This misunderstanding further strengthens household apathy not to process this potential coconut fiber.

\subsection{Potential Crafts that can be Developed from Coconut Fiber}

There are many potential crafts that can be developed from coconut fiber. This potential if it can be utilized properly, can overcome the economic problems of poor households to improve welfare. First is the house broom. House brooms made from coconut fiber have been widely used in various regions in Indonesia. Unfortunately, this has not been fully developed at the research site. The actual method of making house brooms from coconut fiber is quite simple. First, the coconut fiber is soaked in water, then pounded with wood or stone until smooth, then dried in the sun to dry. After drying, then knit with palm fiber or plastic rope, and tied to a piece of bamboo or rattan. The making of house brooms made from coconut fiber is done traditionally, namely by handicrafts. This causes the time needed to work on a broom requires a relatively long time. This broom product is very prospecting if it can be developed better and become an economical source for poor households.

Second, coconut fiber can be developed into a mattress. The mattress made from coconut fiber is a combination of coconut fiber and rubber latex, which produces a high-quality product. It is because these mattresses do not need to use springs anymore. The coconut fiber and rubber mattress are naturally supple and soft. The results of the natural curling process of coconut coir and rubber fibers have natural flexibility and flexibility. Other advantages of this mattress are anti-bacterial, easy to clean and dry quickly. Thus, this coconut fiber mattress is certainly healthy for babies and children. Genuine rubber coconut fiber made from coconut coir fibers which are printed or arranged in such a way as sheets which are then sprayed with original latex compound and dried so that it becomes a good whole. The result is a good mattress for sometimes hot and suddenly cold weather conditions because this mattress will produce a warm effect, which is not as hot as a foam mattress when the weather is cold and cool during hot weather. Producing rubbery coconut coir can be adjusted to the conditions of the needs even though it still refers to the existing specifications in general. It makes this coconut fiber mattress ideal for maintaining and improving when there is a perceived health problem.

The third potential of coconut fiber can be made into rope. Coconut coir is the primary material for making various handicrafts made from coconut fiber, such as coir for handicrafts, coconut coats for cords, boat ropes, and others. Coconut coir is the second main ingredient after coco fiber itself. This coir rope has several variations of twist, or often referred to as ply. Generally, for many ropes that use two plies, then three-ply and so on as needed.

House mat is a potential that can also be developed from coconut fiber. Making mats from coconut fiber is done manually by human labor, except the separation of coir or coconut fibers with the powder can be used coconut coir decomposition machine. The manufacturing process is first, prepare it right for weaving the coir, with the elongated pole. Second, prepare a rope that will be arranged by a groove for weaving. Furthermore, woven coconut fiber, put it from the top, arranged in a parallel manner until all of it is fully loaded. Each time getting one line, close it by banging from above, so the mat is full and robust. The results of the plait are then trimmed with a knife or cut out the remnants of coconut fiber.

Another potential of coconut fiber is that it can be developed into a car seat. Processing coconut fiber into a car seat is carried out through three stages of activity, namely immersion, softening, and sealing. The advantages of coconut fiber as a filler for car seats, among others, have excellent flexural strength, are durable, odorless, and have a very low pollution level. Coconut coir can also be developed into handicrafts, such as craft bags. Bags of coconut fiber are still rare and unique. With a little touch of skill, coconut fiber can be made with economically valuable bags. The uniqueness of the craft bag made from coconut fiber can be typical of the region so that it can automatically lift the image of the area in the outside world. 


\subsection{The Strategy of Developing Institutional Economic Business Groups for Poor Households is Based on the Utilization of Coconut Fiber Crafts}

Several strategies can be carried out to develop institutional economic business groups of poor households. The first is through critical awareness. The purpose of critical awareness is to develop a collective understanding of poor households that coconut fiber, which has been seen as a garbage, actually has high economic value. Mefalopulos (2004) stated that critical awareness communication messages are in the form of information, persuasion, promotion, and advocacy with the appeal of rational or emotional messages. Meanwhile, Klandermans (1996) explained that the critical awareness process depends on the personal disposition of the actors (age, experience, and education) and the discourse contestation of the issues that develop.

The second is strengthening capacity. Strengthening capacity is essential for poor households. Strengthening capacitors for poor households have a reciprocal double meaning. On the one hand, capacity building is directed at utilizing individuals so that they are better able to play a role in groups and the wider community, amid the threats they face, both in their personal lives, groups and the wider community. Meanwhile, on the other hand, the strengthening of poor households is directed to see opportunities that develop in the environment of groups and the wider community so that they can be utilized for the improvement of personal, group and wider community life. Strengthening capacity concerning the use of coconut fiber is intended, so that poor households have sufficient skills to be able to process coconut fiber into economically valuable handicraft products. Strengthening the capacity needed by poor households is in the form of skills training, in the form of skills training in processing coconut fiber into high-value value handicraft products, training in business management, bookkeeping training, and marketing training.

Third is on the job training. On the job training is a planned effort to facilitate the learning of knowledge related to work, skills, and behavior by employees (Noe et al., 2006). The on the job training method in empowering households based on coconut fiber processing is provided by facilitating poor households in processing coconut fiber into economically valuable handicraft products. The advantage of using this method is that there is a positive transfer because the training is done in actual employment. Poor households will also be able to know the results of their training right away; a little mistake can cause damage to productivity.

There are six types of methods of job training (Saks \& Haccoun, 2010). i) Job instruction training is on the job training approach that is systemic, structured, and formal. ii) Performance AIDS is on the job training approach that helps poor households to perform well in their jobs. iii) Job rotation is on the job training approach where poor households are trained to be involved in many functions within the organization to be able to adapt and develop the potential for the benefit of the organization. iv) The apprenticeship program is on the job training approach that combines on the job training using the instruction model in the class (in classroom instruction). v) Coaching is on the job training approach in which poor households who have experienced direct other poor households to develop understanding, motivation, skills, and provide support through feedback and reinforcement. vi) Mentoring is an on the job training approach where poor senior households in an organization guide people who are talented in developing junior careers.

Fourth is in-service-training. In-service-training is an effort to improve the knowledge and skills of poor households in processing coconut fiber in order to produce handicraft products of economic value. In-servicetraining, in this case, is all activities given and received by poor households to increase their knowledge, skills, and experience in processing coconut fiber into economically valuable handicraft products. In-service training is given to poor households who are deemed necessary to improve their skills or knowledge by the development of science, especially in the field of coconut fiber craft business. The in-service training program includes various activities such as holding courses, counseling, lectures, workshops, seminars, community surveys, field trips, comparative studies to similar businesses in other regions, and so forth.

The fifth is a comparative study of entrepreneurship. Handicrafts made from coconut fiber have been carried out in other areas with professional management. The progress that has been initiated earlier in a business such as this needs to be used as an example to be applied in research locations that have just started. Poor households in research locations need to get a touch of good examples like this to emulate. In this context, comparative studies are critical to growing the motivation and enthusiasm of poor households for the progress of other regions in utilizing coconut fiber into handicraft products.

Sixth is access to information. Access to information is crucial in its existence to advance the poor household community. With easy access to information, poor households can find out about developments that are far from their community. Especially in the current era of information technology advancement, access to information through the internet, television, scientific journals, and newspapers are a basic necessity. In the current era of 
globalization and information disclosure, it is not too difficult for poor households to access information. The internet network that has reached almost all corners of the region, greatly helps poor households to access information from outside. The problem is that those poor households who can access this information to support their craft business activities are still very minimal. Even if poor households want to access the information, they will be able to plan training properly.

Another strategy is access to micro business financing. No less important in developing the empowerment of poor households is access to finance. Access to finance must be a priority in managing the sustainability system of coconut fiber-based crafts. It is because financing plays an essential role in sustaining business existence. In addition to these strategies, networking also plays a significant role. Networking plays an essential role in strengthening poor households in producing coconut fiber into economically valuable crafts. Networking must involve various existing stakeholders, from government, academics, non-governmental organizations, to local communities. Every existing stakeholder must work together to strengthen poor households to be able to produce coconut fiber crafts to their continuous marketing. Local governments can play a role in strengthening poor households by taking policies that favor poor households. Likewise, academics and non-governmental organizations can take a role by assisting poor households by providing skills training to business development ideas. The local community can take a role by showing empathy to poor households to actively participate in strengthening the institutions of poor household businesses. Local communities are expected to be actively involved in deliberations in their environment that discuss solving the problem of poor households.

\section{Conclusion}

The root of the problem that causes poor households not to use coconut fiber as a source of livelihood can be categorized into several things. Those are the lack of knowledge about the use of coconut fiber, lack of skills, limited education which causes low creativity, low access to quality information, no collective awareness towards the utilization of the local potential of coconut fiber, and there is a false understanding of poor households.

Several potential crafts can be developed from coconut fiber, namely house brooms, mattresses, rope, house mats, car seats, and craft bags. The strategies that can be carried out to develop institutional economic business groups of poor households based on the manufacture of coconut fibre crafts are critical awareness of poor households, strengthening capacity, on the job training, service training, comparative study of entrepreneurship, opening up access to information, opening access to business financing micro, and build networking.

\section{Acknowledgments}

This research was carried out by funding from the Directorate General of Islamic Education, Directorate of Islamic Higher Education, Sub-Directorate Research and Community Service, Ministry of Religion of the Republic of Indonesia. A big thanks to the Director of Islamic Higher Education, Head of Sub-Directorate of Research and Community Service, and Head of Research Section, Ministry of Religion of the Republic of Indonesia for the trust to carry out this research.

\section{References}

Chambers, R. (1995). Poverty and Livelihood: Whose Reality Counts. Discussion Paper 347, Brighton: Institute of Development Studies.

Dharma, P. A. W., Suwastika, A. A. N. G., \& Sutari, N. W. S. (2018). Kajian Pemanfaatan Limbah Sabut Kelapa Menjadi Larutan Mikroorganisme Lokal. E-Jurnal Agroekoteknologi Tropika, 7(2), 200-210

Herdiansyah, H. (2011). Metodologi Penelitian Kualitatif Untuk Ilmu-ilmu Sosial. Jakarta: Salemba Humanika.

Indahyani, T. (2011). Pemanfaatan Limbah Sabut Kelapa pada Perencanaan dan Interior dan Furniture yang Berdampak pada Pemberdayaan Masyarakat Miskin. Humaniora, 2(1), 15-23

Klandermans, B. G. S. (1996). Comparative Perspectives on Social Movement: Political Opportunities, Mobilizing Structures and Cultural Framing in McAdam Editor. Comparative Perspective on Social Movement. USA: Cambridge University.

Kriyantono, R. (2006). Teknik Praktis Riset Komunikasi. Jakarta: PT. Kencana Perdana.

Mefalopulos, K. (2004). Participatory Communication Strategy Design: A Handbook. Second Edition. Rome (IT): FAO.

Moleong, L. J. (2007) Metodologi Penelitian Kualitatif. Bandung: PT. Remaja Rosdakarya.

Mujiyadi, B., \& Gunawan. (2000). Pemberdayaan Masyarakat Miskin (Suatu Kajian Terhadap Masyarakat Sekitar Kawasan Industri). Informasi, 5(1), Jakarta: Balitbang Depsos. 
Nasir, M. (2003). Metode Penelitian. Jakarta: Ghalia Indonesia.

Noe, R. J., Hollenbeck, J. R., Gerhart, B., \& Wright, P. M. (2006). Human Resource Management: Gaining a Competitive Advantage (5th ed). New York: McGraw-Hill.

Paskawati, Y. A., Susyana, A., \& Retnoningtyas, E. S. (2010). Pemanfaatan Sabut Kelapa sebagai Bahan Baku Pembuatan Kertas Komposit Alternatif. Widya Teknik, 9(1), 12-21.

Poerwandari, K. (2007). Pendekatan kualitatif dalam penelitian psikologi. Jakarta: PSP3 Fakultas Psikologi Universitas Indonesia.

Pranarka, A. M. W., \& Moeljarto, V. (1996). Pemberdayaan (Empowerment). Pemberdayaan, Konsep dan Implementasi. Jakarta: CSIS

Saks, A. M., \& Haccoun, R. M. (2010). Managing Performance Through Training and Development. Fifth Edition. Toronto: Nelson Education Ltd.

Soetrisno, L. (2000). Menuju Masyarakat Partisipatif. Yogyakarta: Penerbit Kanisius

Sugiyono. (2009). Metode Penelitian Kuantitatif, Kualitatif dan R\&D, Bandung: Alfabeta.

Sulistiani, W. S. (2014). Pemanfaatan Serabut Kelapa dalam Meningkatkan Kualitas Pupuk Organik dari Ampas Tahu. Bioedukasi, 5(2), 142-150

Titani, F. R., Imalia, C. L., \& Haryanto (2018). Pemanfaatan Serat Sabut Kelapa sebagai Material Penguat Pengganti Fiberglass pada Komposit Resin Polyester untuk Aplikasi Bahan Konstruksi Pesawat Terbang. Techno, 19(1), 23-28.

Trikarlina, E., Sigalingging, R., \& Munir, A. P. (2018). Pemanfaatan Abu Sabut Kelapa (Cocos nucifera L.) dan Pengaruh Penambahan Sikacim Concrete Additive pada Pembuatan Batako. J. Rekayasa Pangan dan Pert., $6(1), 38-43$.

Yusup, P. M., Kuswarno, E., \& Kurniasih, N. (2017). Aspek Keterbatasan Akses Informasi Penghidupan Orang Miskin Pedesaan. Masyarakat, Kebudayaan dan Politik, 30(1), 34-47.

\section{Copyrights}

Copyright for this article is retained by the author(s), with first publication rights granted to the journal.

This is an open-access article distributed under the terms and conditions of the Creative Commons Attribution license (http://creativecommons.org/licenses/by/4.0/). 